\title{
Conspecific recognition and mating in stone marten Martes foina
}

\author{
Thierry LODÉ
}

Lodé T. 1991. Conspecific recognition and mating in stone marten Martes foina. Acta theriol. 36: $275-283$.

The study of the mating of the stone marten Martes foina (Erxleben, 1777) revealed the importance of behavioural modifications which favour the intraspecific tolerance. The precopulatory activities affected the whole mode of communication. The frequencies of the male's olfactory investigation of the female's anogenital region and the male's abdominal scent marking increased at this time. Other signals like a particular muted vocalization, the cluck, or those which interested the general sensitivity like body contact facilitated the female's receptivity and the synchronization of behaviours. The male kept on the female with a neck bite which was similar to the newborn transport behaviour of the female. The male's obstinacy to obtain a positive response from the female seemed to determine successful mating.

Laboratoire d'Ethologie, Université de Rennes I, 35042 Rennes, Cedex, France

Key words: Martes foina, mating behaviour

\section{Introduction}

The stone marten Martes foina (Erxleben, 1777) is an especially common carnivore in Europe. The species frequents a wide variety of habitats including forests (Delibes 1978, Amores 1980, Rasmussen et al. 1986, Labrid 1987), rocky areas (Waechter 1975, Delibes 1978), wooded farmland (Saint-Girons et at. 1988), villages (Waechter 1975, Tester 1986), and towns (Hainard 1961, Clément and Saint-Girons 1982, Holišova and Obrtel 1982, Kalpers 1984, Rasmussen et al. 1986) but presents synanthropic habits in the north of its area that suggests competitive interactions with pine marten Martes martes (Linnaeus, 1758) (Delibes 1983) or at least could result from a certain thermophilia (Waechter 1975).

Because the maintenance of the spacing pattern is greatly affected by the availability of trophic resources (Kalpers 1984, Rasmussen and Madsen 1985, Skirnisson 1986, Labrid 1987, Lodé 1991) home range surfaces vary with habitat and season.

However, like most mustelids, the social organization seems to be based on a relatively strict intrasexual territoriality (Powell 1979). The genus Martes appears to maintain a spatiotemporal segregation of individuals of the same sex but the male's home range could overlap the greatest part of one or several females territories (Schmidt 1943, Pulliainen 1984, Labrid 1987, Marchesi 1989).

Because of their solitary habits, the negative interactions predominate in the stone marten. However, during the breeding season, the animals develop modes of communication which inhibit the aggressiveness and extend the intraspecific tolerance. 
We are interested in the study of behavioural modifications which occur during the breeding period of this species. Direct observations of development of the social behaviour are described thus contributing to a more accurate picture of the biology of this solitary mustelid.

\section{Materials and methods}

The observations were conducted during the years 1989/1990 on two separate pairs of stone marten Martes foina (Erxleben, 1777), live-trapped in western France and kept in two outside enclosures of $16 \mathrm{~m}^{2}$. The first male three years old, weighing $1650 \mathrm{~g}$, was investigated with two years old female weighing $1250 \mathrm{~g}$. The second pair was made up of two years old male weighing $1400 \mathrm{~g}$ and two years old female, weighing $1150 \mathrm{~g}$. Each animal was housed in a separate wood nest box. Water was provided ad libitum but food (dead mice, day-old chickens, and fruit) was daily given at about 18.00 (T.U.). Observations were made from sunset to sunrise between May and September in sessions of $2-4 \mathrm{H}$ duration. They covered complete activity for a total period of 268 hours using a permanent red light to facilitate identification of the animals. Every occurrence of each behaviour pattern was noted and timed for each animal: locomotion, social interactions, vocalizations, scent marking, nuzzle, eating, drinking, grooming, resting, elimination. Detailed records of the behaviour were made from an observation hide.

\section{Results}

In stone marten, the rutting extended from June until August and important physiological modifications came with the first behavioural expressions. The ponderal evolution of testes was maximal during July and the follicular maturation was accompanied by a strong congestion of the vulva.

\section{Conspecific recognition}

From the end of June, the male appeared more and more nervous. The olfactory identification played an important role in the conspecific recognition. The male actively explored his environment and investigated very frequently all defaecation sites from the beginning of an activity period. The frequency of males' abdominal scent marking intensified between June and August and then abruptly declined (Fig. 1), whereas, the frequency of the males' anal scent marking remained stable enough with about 2 per hour with no significant differences between the two males.

$$
\text { Per hour }
$$

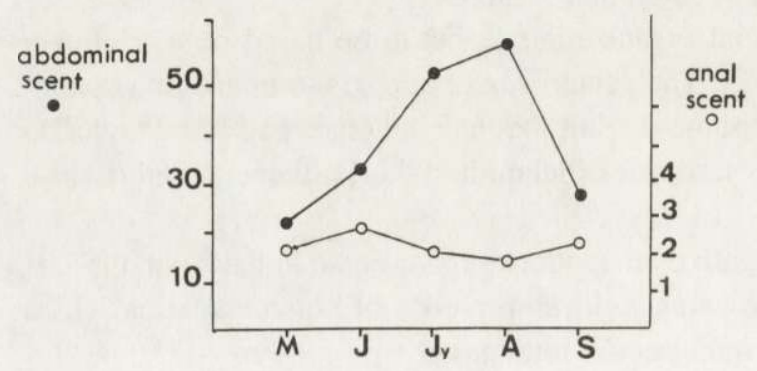

Fig. 1. Frequencies of the male's scent marking between May and September. 


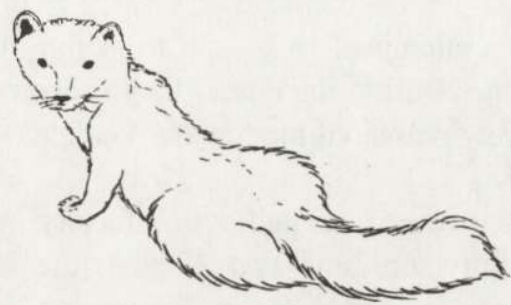

A

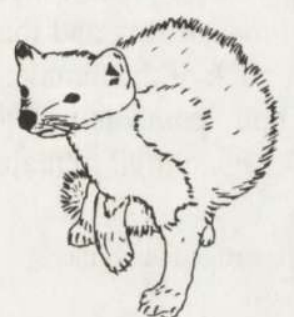

B

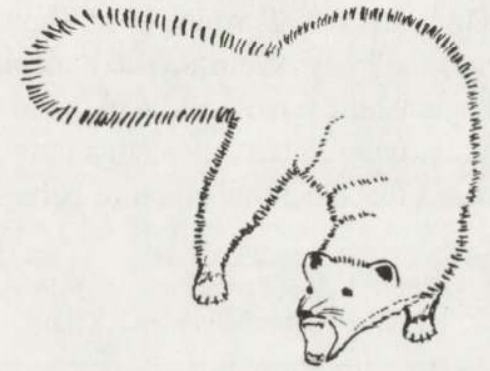

C

Fig. 2. (A) Male's abdominal scent marking, (B) Male's approach towards the female, (C) Female's defensive posture.

In the abdominal scent marking, the male rubbed the ventral body region on the ground or against the substrate (Fig. 2A). This scent marking pattern could last a few minutes. It was sometimes followed by a micturition. The female could show analogous action in which the vulva touched the substrate.

The male's aggressiveness was inhibited and he focused his attention on the female. The male mostly initiated the direct olfactory controls and employed a wide range and numerous changes of approach behaviour. He moved towards the female, put up the foreleg and presented a slight piloerection of the tail (Fig. 2B). At the beginning, when the male chased her, the female showed a defensive posture with piloerection of the tail and open mouth pattern (Fig. 2C). If the male persisted in his attempts, despite her threats, she could attack and bit on the face or the ear region of the conspecific.

A great number of vocalizations accompanied these visual expressions. During the agressive interaction, the female growled and shouted with shrill "staccato". The growling presented variable intensities in low frequencies and preceded the shouts. The female also uttered very high little plaintive cries. In chasing, the male emitted an excited muted cluck like "ek, ek" which corresponded with a succession of rythmic brief sounds. We observed this kind of acoustic signals only during the rutting but it could be sometimes given by the female. When the male evaded the female's aggression, he could be shrieking. 


\section{Synchronization of behaviours}

Because the female attempted to escape from the male's sollicitations, the preliminary phase lasted a long time. During the chase, they followed one another but the regular cluck of the male progressively reassured the female. The male ran towards the female maintaining close proximity to her.

The male's approach was associated with olfactory investigation of the female's neck or ano-genital region. Between June and August, the frequency of the males' olfactory investigation appreciably increased depending on the females' body region (Table 1). The oldiest male (M1) seemed more concentrate his olfactive investigations of the ano-genital region of the female than the youngest male (M2) whereas M1 forsook more other parts of female's body, spot and tail notably (Table 2). However, these differences between the two males were not significant.

At the beginning, the female rolled over, showed an aggressive posture with shrieking and attempted to evade the body contacts. The male multiplied the sniffing and the body contacts, rubbing himself against the female and seeking to reach the neck of the female. The succession of clucks, the numerous olfactive investigations and the body contacts probably calmed the female and favoured the synchronization of behaviours. The male tried to maintain the female

Table 1. Mean frequency of male's olfactory investigation on the females between June and August.

\begin{tabular}{lrrc}
\hline Body region & June & July & August \\
\hline Muzzle & 27.8 & 15.5 & 10.0 \\
Ear/neck & 15.4 & 23.3 & 20.8 \\
Spot & 4.8 & 2.2 & 1.5 \\
Back/rump & 11.5 & 3.3 & 4.6 \\
Ano-genital & 31.7 & 52.2 & 56.1 \\
Tail & 8.6 & 3.3 & 7.0 \\
$n$ & 104 & 90 & 130 \\
\hline
\end{tabular}

Table 2. Frequency of the two males (M1, M2) olfactory investigation on the females between June and August. $n$ - number of observations, NS - not significant.

\begin{tabular}{lccccccc}
\hline \multirow{2}{*}{ Body region } & \multicolumn{2}{c}{ June } & \multicolumn{2}{c}{ July } & \multicolumn{2}{c}{ August } & $\chi^{2}$ value, \\
& M1 & M2 & M1 & M2 & M1 & M2 & $p=0.05$ \\
\hline Muzzle & 28 & 27.8 & 15.5 & 15.5 & 8.2 & 11.6 & $0.476 \mathrm{NS}$ \\
Ear/neck & 14 & 16.7 & 22.2 & 24.4 & 19.7 & 21.7 & $0.035 \mathrm{NS}$ \\
Spot & 4 & 5.5 & - & 4.4 & - & 2.9 & $3.952 \mathrm{NS}$ \\
Back/rump & 12 & 11.1 & 4.4 & 2.2 & 4.9 & 4.3 & $1.292 \mathrm{NS}$ \\
Ano-genital & 32 & 31.5 & 55.5 & 48.9 & 63.9 & 49.3 & $0.638 \mathrm{NS}$ \\
Tail & 10 & 7.4 & 2.2 & 4.4 & 3.3 & 10.1 & $3.572 \mathrm{NS}$ \\
$n$ & 50 & 54 & 45 & 45 & 61 & 69 & \\
\hline
\end{tabular}


with a neck bite which seemed similar to the way the carnivores transport the newborn. This neck bite was facilitated in mustelids because the region of neck possessed a prominent subcutaneous fat layer. The pursuit of the mating was dependent upon the response of the female. The receptive female was quiet at that time and soon presented ataxia so that copulation followed.

\section{Copulation}

When the female showed a receptive reaction, the male mounted the female from behind. The forelegs were firmly clasping the female's side and the male grasped the scruff of the female's neck rounding his back and moved back the pelvis (Fig. 3). The female lightly lifted the pelvis up to facilitate the intromission of the penis and stayed still in a characteristic posture which induced copulation.

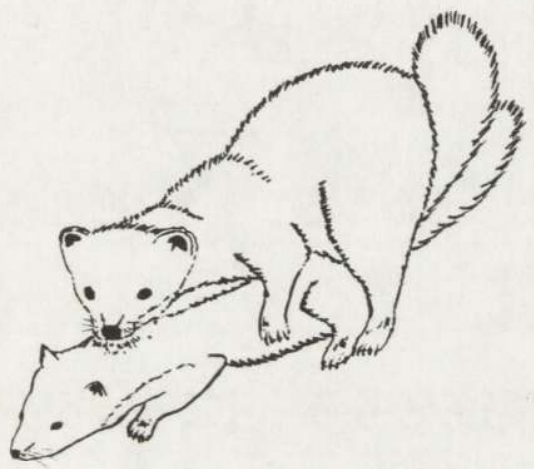

Fig. 3. Copulation

The male's neck bite was maintained throughout copulation which could last more than one hour. The first mating we observed lasted 109 minutes and happened at 21.50 (T.U.). The other matings happened at 3.10 and at 22.15 and lasted 24 minutes and 56 minutes respectively. The animals remained silent but the female could emit muted growlings. After copulation, the female rolled with vigour and developed an intensive grooming chiefly orientated towards vulva region.

Table 3 summarised the whole sequence of the apparent behaviours. The progress of the sequence could be broken in at each point by the female. Indeed $83 \%$ of the males' attempts terminated with an aggressive response of the females (Table 4) with no significant differences

Table 4. Frequency of females responses to the males initial behaviour pattern.

\begin{tabular}{lcccccc}
\hline & $\begin{array}{c}\text { Approach } \\
\text { clucking }\end{array}$ & $\begin{array}{c}\text { Sniffing } \\
\text { muzzle }\end{array}$ & $\begin{array}{c}\text { Sniffing } \\
\text { ano-genital }\end{array}$ & $\begin{array}{c}\text { Body } \\
\text { contact }\end{array}$ & $\begin{array}{c}\text { Neck- } \\
\text { bite }\end{array}$ & Total \\
\hline Agonistic (biting) & 88.9 & 77.3 & 90.9 & 78.9 & 38.5 & 82.9 \\
Evading (rolling) & 9.4 & 22.6 & 6.9 & 16.5 & 34.6 & 13.3 \\
Receptivity & 1.6 & 0 & 2.1 & 4.6 & 26.9 & 3.7 \\
$n$ & 127 & 53 & 143 & 109 & 26 & 458 \\
\hline
\end{tabular}


Table 3. Summary of the sequence of the apparent behaviours, connected with copulation.

\begin{tabular}{|c|c|c|}
\hline Male & & Female \\
\hline Exploring environment & & Exploring environment \\
\hline Approach & $\rightarrow$ & Running \\
\hline Chasing "ek, ek" call & & Growling threat \\
\hline Sniffing muzzle lifting up the foreleg & $\rightarrow$ & $\begin{array}{l}\text { Shrieking } \\
\text { Biting }\end{array}$ \\
\hline Sniffing neck or ano-genital region & $\rightarrow$ & Evading \\
\hline Body contact & $\rightarrow$ & $\begin{array}{l}\text { Rolling over } \\
\text { Shrieking } \\
\text { Evading }\end{array}$ \\
\hline Neck biting & $\rightarrow$ & Ataxia \\
\hline $\begin{array}{l}\text { Mounting } \\
\text { Pelvic thrusts }\end{array}$ & & Lifting up pelvis \\
\hline Copulation & & Copulation \\
\hline $\begin{array}{c}\text { Grooming } \\
\text { * }\end{array}$ & & $\begin{array}{c}\text { Rolling and grooming } \\
\text { * }\end{array}$ \\
\hline
\end{tabular}


between the two females' behaviour. The successful mating largely appeared to be related to the duration and the number of attempts, i.e. to the male's level of motivation.

\section{Discussion}

In stone marten, the establishment and maintenance of the social interactions depended upon inhibition of aggressive behaviour patterns. Important behavioural modifications favoured the increase of intraspecific tolerance. The preliminary activities of the mating affected the whole mode of communication: visual signals, olfactory signals, acoustic signals like those which interested the general sensitivity as body contact.

The olfactory investigations and scent marking played a dominant role in mating activities of numerous small carnivores (Roeder 1979, Harper and Jenkins 1981, Kruuk et al. 1984, Lodé 1990).

The male's abdominal scent marking seemed to take on a primordial importance and increased at this period. This particular pattern of scent marking was also observed in other carnivores (Clapperton 1989) notably in pine marten (Monte and Roeder 1990). The presence of a body rubbing was noticed in mustelids as well (Erlinge et al. 1982, Clapperton 1989). The visual signals like piloerection of the tail and open mouth, appeared the least pertinent signals in the context of mating. They were chiefly associated with aggressive behaviour. It was also the case of most acoustic signals which corresponded to agonistic vocalizations. The growling and shrieking emitted by the female could be identified as threat and attack signals. But the cluck ("ek, ek" call), the body contact and the male's olfactory investigations of neck and ano-genital region of the female's body seemed to function as inhibition of the female's aggressive response.

Numbers of mustelids presented a similar cluck or cackling which looked like an appeasement vocalization (Markley and Basset 1942, Schmidt 1943, Peters 1984, Lodé 1990, Monte and Roeder 1990). Sniffing of the female's genital region was a conspicuous precopulatory activity in small carnivores (Roeder 1979, Rood 1980). Considering these vocalizations, the increase of scent marking and the olfactory investigations, the mating seemed to present a certain homogeneity in mustelids. The behaviour patterns facilitated the conspecific recognition and favoured the receptivity of the female. The stone marten's sexual maturity was reached at about 2 years old (Danilov and Tumanov 1972, Madsen and Rasmussen 1985). The important role of the mother in the acquisition of predation behaviour pattern could be shown during the ontogeny in the polecat Mustela putorius (Lodé 1989) and Diener (1985) underlined that social play of young ferrets could probably affect the sexual behaviour. It will be intersting to specify how the precocial experience intervenes on the establishment of social relations in martens.

The changes of behaviour were linked to physiological modifications which occurred with rutting. The maxima of ponderal variation of testes was reached between June and August (Schmidt 1943, Canivenc et al. 1968, Danilov and Tumanov 1972, Audy 1976a, Madsen and Rasmussen 1985) and could be influenced by the photoperiod in correlation with the secretion of melatonin (Audy 1976b, Almeida and Lincoln 1984). The stone marten had delayed implantation of blastocytes and the nidation was under the influence of the photoperiod through 
the medium of hypothalamus (Canivenc et al. 1968, Canivenc 1970, Canivenc et al. 1981, Mead and Wright 1983). So the female came into oestrus shortly after parturition and after the young's breeding where the male was excluded.

Aggressive motivations often interfered with sexual behaviour. The parturition activity probably negatively interacted with the sexual behaviour. The development of the preliminary phases performed by the male (sniffing, clucking, and body contact) progressively favoured the female motivational change. The numerous aggressions by the female did not inhibit the male's sexual resolution. These behavioural modifications could be a form of an inversion of the customary dominance; the male suffering most of the aggressions. Then, the changes of behaviour made an important contribution to the initiation of mating. The male's obstinacy to maintain close proximity and body contact and the employment of a wide range of approaches were mainly going to determine successful mating. Poole (1974) stressed that the status depended more upon the animal's motivation than the weight of individuals in polecat. So, the fact that social status probably determined successful sexual behaviour in stone marten could be presumed.

Acknowledgements: I am most grateful to D. Le Jacques for her presious help and to C. Huchede of the refuge de l'Arche.

\section{References}

Almeida A. F. X. and Lincoln G. A. 1984. Central mechanisms in the control of seasonal breeding. Acta Zool. Fenn. 171: $151-156$.

Amores F. 1980. Feeding habits of the sone marten Martes foina (Erxleben, 1777) in south-western Spain. Säugetierk. Mitt. 28: $316-322$.

Audy M. C. 1976a. Le cycle sexual saisonnier du mâle des Mustélidés européens. General and comparative endocrinology 30: $117-127$.

Audy M. C. 1976b. Influence du photopériodisme dans la physiologie testiculaire de la Fouine Martes foina. C. R. Acad. Sc. Paris 283: $805-808$.

Brosset A. 1974. Mammiferres sauvages de France et d'Europe de l'Ouest. Nathan, Paris: $1-168$.

Canivenc R. 1970. Photoperiodisme chez quelques mammifêres à nidation différée. Coll. CNRS, Photoregulation de la reproduction: $453-469$.

Canivenc R., Bonnin-Laffargue M. and Relexans M. C. 1968. Cycles génitaux de quelques Mustelidés européens. Entretiens de Chizé 1: 95 - 110.

Canivenc R., Mauget C., Bonin M. and Aitken J. 1981. Delayed implantation in the beech marten Martes foina. J. Zool., Lond. 193: 325 - 338 .

Clapperton B. K. 1989. Scent marking behaviour of the ferret (Mustela furo L.). Anim. Behav. 38: 436 - 446.

Clément R. and Saint-Girons M. C. 1982. Le régime de la Fouine Martes foina Erxleben 1777 dans l'agglomération nantaise et en milieu rural. Mammalia 46: 550 - 553.

Danilov P. I. and Tumanov I. L. 1972. Reproductive cycles of males and females in some of the Mustelidae species. Zool. Ž. 51: 871 - 880. [In Russian with English summary]

Delibes M. 1978. Feeding habits of the stone marten (Martes foina Erxleben, 1777) in northern Burgos, Spain. Z. Säugetierk. 43: $282-288$. [In Russian with English summary]

Delibes M. 1983. Interspecific competition and the habitat of the stone marten Martes foina (Erxleben, 1777) in Europe. Acta Zool. Fenn. 174: 229 - 231.

Diener A. 1985. Verhaltensanalysen zum Socialspiel von Iltisfrettchen (Mustela putorius furo). Z. Tierpsychol. 67: $179-197$. 
Erlinge S., Sandell M. and Brinck C. 1982. Scent marking and its territorial significance in stoats Mustela erminea. Anim. Behav. 30: $811-818$.

Hainard R. 1961. Mammifères sauvages d'Europe. Delachaux and Nièstlé, Neuchatel-Paris: 1 - 332.

Harper R. J. and Jenkins D. 1981. Mating behaviour in the European otter. J. Zool., Lond. 195: 556 - 558.

Holišova V. and Obrtel R. 1982. Scat analytical data on the diet of urban stone marten Martes foina (Mustelidae, Mammalia). Folia zool. 31: 21 - 30.

Kalpers J. 1984. Contribution à l'étude écoéthologique de la Fouine Martes foina. Stratégies d'utilisation du domaine vital et des ressources alimentaires. II radiorepérage et discussion générale. Cahiers Ethol. Appl. 4: $11-26$.

Kruuk H., Gorman M. and Leitch A. 1984. Scent marking with the subcaudal gland by the European badger Meles meles. Anim. Behav. 32: 899 - 907.

Labrid M. 1987. La Martre Martes martes et la Fouine Martes foina : utilisation de l'espace et du temps et régime alimentaire de deux Mustélidés sympatriques en milieu forestier. Thesis Univ. Paris VIII: $1-161$.

Lodé T. 1989. Ontonégènse des comportements de prédation et rôle de l'expérience alimentaire précoce chez Mustela putorius. Mammalia 53: 497 - 509.

Lodé T. 1990. Reconnaissance du congénère et comportement sexual chez un Mustélidé: le Putois Mustela putorius. Bull. Soc. Sc. Nat. Ouest France. Muséum Nantes 12: $105-110$.

Lodé T. 1991. Exploitation des milieux et organisation de l'espace chez deux Mustélidés européens : la Fouine Martes foina et le Putois Mustela putorius. Vie et Milieu 41: 29 - 38.

Madsen A. B. and Rasmussen A. M. 1985. Reproduction in the stone marten Martes foina in Denmark. Natura Jutl. 21: $145-148$.

Markley M. H. and Basset C. F. 1942. Habits of captive marten. Am. Midl. Nat. 28: 605 - 616.

Marchesi P. 1989. Ecologie et comportement de la Martre (Martes martes L.) dans le Jura suisse. Thesis, Neuchatel: $1-185$.

Mead R. A. and Wright P. L. 1983. Reproductive cycle of Mustelidae. Acta Zool. Fenn. 174: 169 - 172.

Monte M. (de) and Roeder J. J. 1990. Les modalités de communication chez la Martre (Martes martes). Mammalia 54: 13 - 24.

Nicht M. 1969. Ein Beitrag zum Vorkommen des Steinmarders, Martes foina (Erxleben, 1777) in der Grossstadt (Magdeburg). Z. Jagdwiss. 15: 1-6.

Peters G. 1984. On the structure of friendly close range vocalizations in terrestrial carnivores (Mammalia: Carnivora: Fissipedia). Z. Säugetierk. 49: $157-182$.

Poole T. B. 1974. The effect of oestrus condition and familiarity on the sexual behaviour of polecats (Mustela putorius and $M$. furo $\times$ M. putorius hybrids). J. Zool., Lond. 172: $357-362$.

Powell R. A. 1979. Mustelids spacing pattern: variations on a theme by Mustela. Z. Tierpsychol. 50: 153 - 165 .

Rasmussen A. M. and Madsen A. B. 1985. The diet of the stone marten Martes foina in Denmark. Nat. Jutl. 21: $141-144$.

Rasmussen A. M., Madsen A. B., Asferg T., Jensen B. and Rosengaard M. 1986. Undersøgelser over husmåaren (Martes foina) i Danmark. Danske Vild. Haefte 41: 1 - 39.

Roeder J. J. 1979. La reproduction de la Genette $G$. genetta L. en captivité. Mammalia 43: 531-542.

Rood J. P. 1980. Mating relationships and breeding suppression in the Dwarf mongoose. Anim. Behav. 28: $143-150$.

Saint-Girons M. C., Lodé T. and Nicolau-Atlantique. Atlas des mammiferes terrestres de Loire-Atlantique. Muséum National d'Histoire Naturel, Paris: 1 - 103.

Schmidt F. 1943. Naturgeschichte des Baum- und des Steinmarders. Monograph. Wildsäugetiere 10: $132-244$.

Tester V. 1986. Vergleichende Nahrungsuntersuchung beim Steinmarder Martes foina (Erxleben, 1777) in grossstädtischen und ländlichem Habitat. Säugetierk. Mitt. 33: 37 - 52 .

Waechter A. 1975. Ecologie de la Fouine en Alsace. Rev. Ecol. Terre et Vie 29: 399 - 457.

Received 10 June 1991, accepted 26 November 1991. 